\title{
A PSYCHOSEMANTIC STUDY OF COMPENSATION PSYCHOLOGICAL DEFENSE MECHANISM IN THE NOVICE MILITARY LEADERS
}

\author{
Tetyana Khraban \\ xraban.tatyana@gmail.com \\ https://orcid.org/0000-0001-5169-5170 \\ Heroiv Krut Military Institute of Telecommunications \\ and Information Technologies, Ukraine \\ Ihor Khraban \\ khraban728@gmail.com \\ https://orcid.org/0000-0003-3319-8538 \\ Yevheniy Bereznyak Military Diplomatic Academy, Ukraine
}

Received July 4, 2020; Revised August 28, 2020; Accepted September 2, 2020

\begin{abstract}
The aim of the article is to study the formative impact of the defense mechanism "compensation" on the leader's personality. The research is based on the axiological semantic research method created due to the development and application of experimental psychosemantics to the issue of leadership. An experiment was conducted with the view of confirming the fact of impact of the defense mechanism "compensation" on the leader's personality formation. This experiment involved 30 students undergoing leadership training for tactical officers at the Heroiv Krut Military Institute of Telecommunications and Information Technologies. A test-questionnaire was created to experimentally substantiate the reliability of the proposed conjecture. At the outset of the experiment, the participants were asked to note in the test-questionnaire the basic postulates they rely on when forming relationships in the military community. For the purpose of creating a relaxed atmosphere the postulates (60 units) were presented in the form of posts (quotes and aphorisms) which are most often posted on social media pages. Based on the methods of psychological subjective semantics and psychosemantics, we established the predominance of a certain form of defence mechanism "compensation". Then followed the assessment of the leadership role preferences displayed by the participating pilot students, this providing the basis for drawing conclusions as regards the tendency for a particular form of leadership. Matching of the obtained results revealed correlations between mental reflections of various phenomena. Although correlational study has a lower degree of confidence in predicting cause and effect, it can provide strong indications that relationships exist. Results and discussions. The defense mechanism "direct compensation" correlates with the kind of "fighter" leader, "overcompensation" correlates with the kind "father", "decompensation" correlates with the kind "tyrant". To conclude, trend to use a certain type of defense mechanism affects the acceptance and assimilation of a certain role type of leader. In addition, the use of information which are most often posted by social media users on their personal accounts as a content for the test-questionnaire allows us to conclude about the possibility of using social media
\end{abstract}

(C) Khraban, Tetyana; Khraban, Ihor, 2020.

This is an Open Access article distributed under the terms and conditions of the Creative Commons Attribution 4.0 International Licence (https://creativecommons.org/licenses/by/4.0/).

East European Journal of Psycholinguistics, 7(2), 97-106. https://doi.org/10.29038/eejpl.2020.7.2.khr 
account to determine the psychological type of personality by analyzing posts, likes, and comments.

Keywords: experimental psychosemantics, leadership, psychological defense mechanism.

Храбан Тетяна, Храбан Ігор. Психосемантичне дослідження психологічного захисного механізму компенсації у майбутніх військових лідерів.

Анотація. Мета статті - вивчення впливу захисного механізму «компенсація» на формування особистості лідера. Дослідження грунтується на аксіосемантичному методі, який створено завдяки розвитку та застосуванню експериментальної психосемантики до проблематики лідерства. Для підтвердження впливу захисного механізму «компенсація» на формування особистості лідера був проведений експеримент, в якому взяли участь слухачі курсів лідерства офіцерського складу тактичного рівня у Військовому інституті телекомунікацій та інформатизації імені Героїв Крут. Для експериментального обгрунтування достовірності запропонованої концепції було створено тест-опитувальник. Спочатку слухачам курсів лідерства офіцерського складу було запропоновано відзначити в тестіопитувальнику основоположні постулати, на які вони спираються при створенні взаємовідносин в колективі. Для створення невимушеної атмосфери постулати (60 одиниць) було представлено у вигляді дописів (цитат і афоризмів), яких найчастіше викладають на сторінках соціальних мереж. Шляхом факторизації семантичних дескрипторів було встановлено переважання певної форми захисного механізму «компенсація». Потім було здійснено оцінку преференції для суб'єкта функцій лідера, на підставі чого зроблено висновки щодо прагнення до визначеної формі лідерства. Кореляція отриманих даних дала змогу виявити зв'язки між психічними відображеннями різних феноменів. Наприклад, механізм психологічного захисту «пряма компенсація» корелює 3 типом лідера «воїн», «надкомпенсація» - 3 типом лідера «батько», «декомпенсація» - 3 типом лідера «тиран». Тенденція використовувати певний тип психологічного захисту «компенсація» впливає на засвоєння і прийняття суб'єктом певного рольового типу лідера. Крім того, використання як наповнення тесту-опитувальника дописів, що найчастіше виставляють користувачі соціальних мереж на своїх сторінках, дає змогу зробити висновок про можливість використання особистих акаунтів в соціальних мережах для визначення психологічного типу особистості шляхом аналізу публікацій (дописів), коментарів і «лайків».

Ключові слова: експериментальна психосемантика, лідерство, механізми психологічного захисту.

\section{Introduction}

One of the main problems of the modern army as a union with the centurylong tradition of leadership is training true leaders who are able to effectively cope with the military task and challenges of the day. Armed Forces' practical experience in combat operations during armed conflicts and peacekeeping operations has shown that command as a process at any level of military management is a combination of leadership and management (Allen, 2006). The reality of enormous constant risks incurred during wars and the critical situations entailed creates a situation when the military system goes beyond rationally organized operational patterns, and the time comes for someone who knows what to do, what resources and where to allocate, as well as what consistency is required and what outcomes are to be achieved. It is a military leader who can be critical of what has been achieved and is able to analyse what is lacking to improve the collective result. And only a military leader can motivate and inspire the others 
towards the final victory by setting an example (Bojko, 2019). Thus, a leader is one who determines the activities of the group, has a significant impact on the behaviour of the group's members, and is able to organize people around a goal. A leader is person whose right to make responsible decisions is recognized by the rest of the group. In this context, leadership is a modern ideal of behaviour (Cutler, 2014; Blanshard, 2019), which is based on one's personal and professional preferences rather than on one's origin and status (Zankovsky, 2011, p.6). Leadership is a socio-psychological phenomenon (Laurence, 2011; Bass, 2008), which within the military specifics is defined as an effect on people through the definition of goals, directions of its achievement, motivation to accomplish the task and improve the military organization (Field Manual, 2015). Military leadership differs significantly from other forms of leadership in a situational context provided by an extreme situation. Since dangers and stress arising under these extreme situations are a common and widespread occurrence in the military profession, it is necessary to teach future officers to how handle them (Bergman et al., 2019). It is indisputable that this factor determines the relevance of leadership studies. However, it should be taken into account that not only the leader's personal qualities determine the effectiveness of the military group (Taylor \& Rosenbach, 2005). The behavioral approach to the study of the phenomenon of leadership, which focuses on the image of the leader as a mechanical set of characteristics, largely devoid of psychological content, ignores issues concerning the subjectivity of the leader, his/her consciousness as a higher form of mental reflection. From that, a line of research based on modern developments in the field of psychology and psycholinguistics seems to be promising. This approach makes it possible to actualize the impact of psychological factors on the mechanism of formation, development and dynamics of the leadership phenomenon, to understand why leadership is not only a form of behavior in certain organizational conditions but it is also a complex mental phenomenon that carries social experience, models and reshapes the individual inner world and capable of development and selfdevelopment (Zankovsky, 2011, p. 7-8). In this case, special consideration should be given to the presence of specific needs that urge an individual to to exercise leadership (Avolio, 2007). Thus, according to the theory of Adler, two innate and unconscious feelings - inferiority and the desire for superiority, are the sources of individual's energy which is necessary for personal development. If the feeling of inferiority affects a person, causes to feel a yearning to overcome shortcomings, the urge for superiority causes a desire not only to overcome the shortcoming as wells to be top of the league (Adler, 2019, p. 185). Thus, Adler notes the role played by the defense mechanism "compensation" in the regulation of the leadership behaviour: such factors as certain needs inducing the dominant behaviour, motives realized by means of such behaviour impact the personal qualities displayed in the relationship between the leader and group members, the desire to strengthen a leadership position, set goals and mobilize group members to implement a task and hence to enhance the effectiveness of the leader (Adler, 2019). The study of the defense mechanism "compensation" aiming to help stabilize self-esteem through 
forging specific relationships with other members of the group (Demina \& Ralnikova, 2004) casts a new light on leadership, allows one to take into account the role of defense mechanisms in regulating leadership behaviour and makes it possible to increase leadership effectiveness.

The phenomenon of leadership is a relevant subject of interdisciplinary analysis. Research on leadership is undertaken within such areas of knowledge as psychology, sociology, philosophy, pedagogy, political science and so on. This problem is especially relevant in the field of military science and education. This has resulted in a body of research in military psychology, namely: Baran \& Scott (Baran \& Scott, 2010) (the research paper highlights leadership as a collective sensemaking process in which ambiguity is reduced and resilience promoted in the face of danger via interaction among and between leaders and followers); Laurence (Laurence, 2011) (the sociocultural knowledge gaps in leader development are highlighted, as are prescriptions of the trait and situational approaches to leadership. Military leaders' dual responsibility for their own troops and the local population requires them to shift interpersonal relationships and leadership styles as the situation demands); Sweeney (Sweeney, 2010) (the study holds that the majority of soldiers reconsider trust in their leaders prior to combat operations, to ensure that they have the competence and character to meet the greater demands of leading in combat); Wong, Bliese, McGurk (Wong et al., 2003) (the research paper reviews the literature on military leadership and highlight research opportunities for leadership scholars. The review uses a context specific approach and turns to a simplified version of Hunt's extended multilevel leadership model as a template to examine the many facets of military leadership). Also important for this article are research papers in the field of psychology and psycholinguistics, namely: Cramer (Cramer, 2015) (the research examines defense as an unconscious mechanism); Burgo (Burgo, 2012) (the research paper adapts the basic strategies of psychodynamic psychotherapy to a guided course in self-exploration, elucidating the universal role of defense mechanisms in warding off emotional pain) and other research efforts. This article highlights the fact that the features of compensatory processes in the system of defense mechanisms lead to the formation of certain psychological types of leaders.

The aim of the article is to study the formative impact of the defense mechanism "compensation" on the leader's personality.

\section{Methods}

The research is based on the axiological semantic research method created due to the development and application of experimental psychosemantics to the issue of leadership (Zankovsky, 2011). Psychosemantics helps to reveal deep, unconscious structures which are considered not an independent psychological reality contrasting consciousness but the lower levels of consciousness characterized by less fragmentation and reflectivity (Petrenko, 2010). The psychosemantic approach to leadership studies helped to emphasize the reconstruction of individual systems of values and meanings in accordance with the way the leader perceives the world 
(Fomina, 2019). An experiment was conducted with the view of confirming the fact of impact of the defense mechanism "compensation" on the leader's personality formation. The experiment involved thirty students undergoing leadership training for tactical officers at the Heroiv Krut Military Institute of Telecommunications and Information Technologies. A test-questionnaire was devised to experimentally substantiate the reliability of the proposed conjecture. By means of methods of psychology subjective semantics and psychosemantics the predominance of a certain form of defense mechanism "compensation" was established. Then the participating pilot students' preferences of leadership roles was assessed, on the basis of which conclusions were drawn about the tendency for a particular form of leadership. In order to clarify the qualities and abilities of a leader we refer to the classification of leader types offered by Wong, Bliese, McGurk (Wong et al., 2003). In their work a context specific approach was used that extended multilevel leadership model as a template to examine the many facets of military leadership. Matching of the obtained results revealed correlation between mental reflections of various phenomena. "Although correlation does not mean causation, it can show strong relationships between variables. It can show the direction and magnitude of a relationship, yet still cannot predict cause and effect with $100 \%$ accuracy. A correlational design will provide relationship direction and degree. Although correlational studies have a lower degree of confidence in predicting cause and effect, it can provide strong indications that relationships exist" (Adams, 2009).

\section{Results and Discussion}

One of the most common type of defense mechanisms in the system of adaptive human reactions is "compensation", which manifests itself in three metaforms: "direct compensation", "overcompensation" and "decompensation". In all cases one way or another "compensation" solves the problem of harmonizing the communicative world of the individual (Gladyshev, 2001, p. 25) by overcoming and compensating for shortcomings in the process of development of partially preserved functions in the affected area (overcompensation) or intensive development of abilities in another area (compensation) (Vaughan, 1926).

A survey was conducted with the view of finding out what type of defense mechanism "compensation" is preferable for the individual. Initially, students of leadership course were asked to note in the test-questionnaire the basic postulates on which they are based while creating relationships in the military collective. For the purpose of creating a relaxed atmosphere the postulates (60 units) were presented in the form of posts (quotes and aphorisms) which are most often posted on social media pages of various individuals and which effect on people's behavior basing mainly on socio-psychological contacts and socio-psychological methods of management.

Preference of those postulates that at the language level reflect the concentration of the individual on his interests, feelings and needs, reflect consumerism: Я розмовляю сам з собою, тому щзо я єдина людина, чиї відповіді мені подобаються (Eng. The reason I talk to myself is because I'm the only one 
whose answers I accept) (FB, 2020) indicates the involvement of the defense mechanism "direct compensation", which is innately adaptive and does not take the individual beyond the usual (familiarized) communicative world, does not contribute to his personal growth (Gladyshev, 2001, p. 17).

The preference for those postulates which employ the crystallized image (real or illusory) to enhance the individual's power, significance, value, that is for selfaffirmation and improvement of the status: Коли в компанію приходить одна розумна людина, незабаром з'являється і інший - талановиті люди люблять працювати в колі собі рівних; Навіть в компанії двох чоловік я неодмінно знайду, чому у них повчитися (Eng. As soon as one smart person comes to the company another one soon appears since talented people like to work among equal to themselves; Even in the company of two people I will definitely find something to learn from them) (FB, 2020) demonstrates the use of defense mechanism "overcompensation", which is associated with maladaptive forms of activity and is realized by relying mainly on secondary, additional compensation (in its creative, exploratory forms). Communicatively, "overcompensation" promotes personal growth and radical transformation of the personality through dialogic affirmation (Gladyshev, 2001, p. 17). Preference for postulates characterized by the faultfinding when another person's imaginary or real shortcomings are emphasized or exaggerated: Іноді я думаю, щуо Бог, створюючи людину, переоцінив Свої можливості; Всі ми народжуємося божевільними. Деякі ними і залишаються (Eng. Sometimes I think that God in creating man somewhat overestimated His ability; We all are born crazy. Some of us remain that way) (FB, 2020) confirms the call to the defense mechanism "decompensation". "Decompensation" aims at balancing the changes that occur in a dynamic system and unbalance it. The action of defense mechanism leads to a new state of dynamic equilibrium at a more elementary level of order, complexity and organization. As a means of compensatory communication "decompensation" ultimately leads to the destruction of the social actors and the deformation of the communication sphere in which they are included (Gladyshev, 2001, p. 17; Haynes, 2017).

In the second part of the test-questionnaire the students of leadership were asked to note what functions, in their opinion, a leader should perform, for example: to make all important decisions independently; to carry out the decisions by military superiors; to share responsibility for decision-making with others; to monitor the progress of the work done by their subordinates; to help others; to stimulate self-control; to fulfil the role of an expert who single-handedly finds solutions to any problem; to act as a facilitator who asks questions and elicits answers from other group members; to draft tasks and rules; to shape their subordinates' worldviews; to administer punishment for breaches of discipline; to protect the subordinates' interests; to support the initiative; to promote competitiveness; to organize cooperation; to encourage teamwork; to create conditions for productive and successful work; to assist the subordinates in resolving issues relating to social and living conditions; to help organize and rationalize the subordinates' leisure; to share the responsibility and power; to 
supervise the implementation of instructions; to support stability; to support transformation.

In matching the results of the first part of the test-questionnaire to the second part, it was concluded that the tendency to use a certain type of defense mechanism "compensation" impacts the acceptance and assimilation of a certain role type of leader (Table 1).

Table 1.

Correlation between the defense mechanism "compensation" forms and particular forms of leadership

Postulates featuring certain Percentage of preferable postulates ( \%) defense mechanisms

1. "Direct compensation"

\begin{tabular}{ccc}
\hline Leader "fighter" & Leader "father" & Leader "tyrant" \\
\hline 69 & 31 & 22 \\
10 & 67 & 5 \\
21 & 2 & 73 \\
\hline
\end{tabular}

2. "Overcompensation"

3. "Decompensation"

The defense mechanism "direct compensation" correlates with the type of "fighter" leader. This is a strong-willed, self-confident person: Ніколи ні на кого не надійся. Люди, на яких ти сподіваєшся, можуть підвести, зрадити, забути про тебе. Сподівайся тільки на себе! (Eng. Never rely on anyone. People you rely on can let you down, betray you, forget about you. Rely only on yourself!) (FB, 2020) who meets danger or uncertainty without fear and does not hesitate to join a fight: Якщо мене щзось $і$ рухає вперед, то тільки моя слабкість, яку я ненавиджу і перетворюю в мою силу (Eng. If anything moves me forward, it is only my weakness that I hate and turn into my strength) (FB, 2020), defends his believes: Я бажаю робити в своєму житті те, що я люблю. А не те, щзо є модним, престижним чи встановленим (Eng. I want to do in my life what I like. Not what is fashionable, prestigious or established) (FB, 2020), reluctant to compromise: Я зовсім не хочу знати, що говорять за моєю спиною - я і без того про себе достатньо високої думки (Eng. I do not want to know what is being said behind my back since I have a high opinion of myself) (FB, 2020).

Interrelation can be traced between defense mechanism "overcompensation" and the type of "father" leader, which is characterized by such descriptors: individual perceives needs of the team as his own and he is active to meet needs of all his subordinates: Бути людиною - це відчувати свою відповідальність. Відчувати сором перед убогістю, яка, здавалося б, і не залежить від тебе. Пишатися кожною перемогою, здобутої товаришами (Eng. To be a huтап is to feel responsibility, to feel ashamed of poverty, which seemingly isn't up to you. Be proud of every victory won by comrades) (FB, 2020), he is optimistic, confident and believes that most problems can be fully resolved: Тренуйся - щоб бути рівним суперником, настройся - щоб перемогти! (Eng. In order to be an equal opponent you should train, in order to win you should set the mood on victory!) 
(FB, 2020), he knows how to persuade, tends to encourage and expresses disapproval without affecting the subordinates' dignity: Якщо ти віриш у себе до тебе тягнуться й інші, якщо ти вселяє віру в інших - ти стаєш ще більш впевненим у собі, а значить - ще більше удачливим і успішним (Eng. If уои believe in yourself others are drawn to you, if you inspire faith in others you become even more confident, and therefore you become even more successful) (FB, 2020).

Causal relations were found between the defense mechanism "decompensation" and the type of "tyrant" leader, whose features are dominance in communication, the desire to suppress and subdue the interlocutor personality, communicative aggression: Ну не мінятися ж мені через кожного idioma! (Eng. Well, I do not change for the sake of idiot!) (FB, 2020), cognitive egocentrism: Себе треба любити і хвалити - не доручати ж таку відповідальну справу чужим людям! (Eng. You must love and praise yourself because it is impossible to trust so great matter to strangers!) (FB, 2020), unwillingness to understand the interlocutor, disrespect for another's point of view, communicative rigidity: Xmo иінує людську думку - надає людям занадто багато честі! (Eng. Who values human thought gives people too much credit!) (FB, 2020).

\section{Conclusions}

Psychological defense mechanisms play an important role in regulating leadership behaviour. The tendency to use a particular type of defense mechanism affects the acceptance and assimilation of a particular leadership role type. Thus, the defense mechanism "direct compensation" correlates with the kind of "fighter" leader, "overcompensation" correlates with the kind "father", "decompensation" correlates with the kind "tyrant". In addition, the use of information which are most often posted by social media users on their personal accounts as the content for the test-questionnaire allows us to conclude about the possibility of using social media account to determine the psychological type of personality by analyzing posts, likes and comments. The advantage of such testing is the openness (availability) of information on social networks as well as the quality of the analyzed material. Unlike information in questionnaires, which can be distorted due to nervousness arising during filling in the questionnaire (especially for career growth) or unwillingness to reveal the true nature of one's identity for various reasons, information obtained from social media is reliable and sincere.

\section{References}

Бойко О. Лідерство як душа армії. 2019. URL: https://petrimazepa.com/uk/liderstvo_yak_dusha_armii

Гладышев В. И. Компенсаторное общение: социально-философский анализ: автореф. дисс. ... д-ра филос. наук. Екатеринбург, 2001.

Занковский А.Н. Психология лидерства: от поведенческой модели $к$ культурноценностной парадигме: монография. Москва: Институт психологии РАН, 2011.

Петренко, В. Ф. (2010). Многомерное сознание: психосемантическая парадигма. Москва: Новый хронограф. 
Фомина Н. Отражение в речи индивидуально-типологических особенностей языковой личности. Psycholinguistics. 2019. Вип. 26, № 1, 342-362. https://doi.org/10.31470/23091797-2019-26-1-342-362

Adams, D.L.( 2009). Personality Type and Leadership Approach. Journal of Leadership Education, 8(2), 111-134. https://doi.org/10.12806/v8/i2/rf1

Adler, A. (2019). The Fundamental Views of Individual Psychology. The Journal of Individual Psychology, 75(3), 185-187. https://doi.org/10.1353/jip.2019.0023

Allen, N. (2006). Leader development in dynamic and hazardous environments: Company commander learning in combat. Doctoral dissertation, The George Washington University, Washington, DC.

Avolio, B.J. (2007). Promoting more integrative strategies for leadership theory-building. American Psychologist, 62(1), 25-33. https://doi.org/10.1037/0003-066X.62.1.25

Baran, B.E. \& Scott, C.W. (2010). Organizing Ambiguity: A Grounded Theory of Leadership and Sensemaking Within Dangerous Contexts. Military Psychology, 22, 42-69. https://doi.org/10.1080/08995601003644262

Bass, B., Bass, R. (2008). The Bass Handbook of Leadership: Theory, Research, and Managerial Applications. 4th Ed. New York: Free Press.

Bergman, D., Sendén, M.G., Berntson, E. (2019). Preparing to lead in combat: Development of leadership self-efficacy by static-line parachuting. Military Psychology, 31, 481-489. https://doi.org/10.1080/08995605.2019.1670583

Blanshard, C. (2019). Leadership in the spotlight. BMJ Leader, 3, 65-66. https://doi.org/10.1136/leader-2019-000155

Burgo, J. (2012). Why Do I Do That? Psychological Defense Mechanisms and the Hidden Ways They Shape Our Lives. Chapel Hill, NC: New Rise Press.

Cramer, P. (2015). Understanding defense mechanisms. Psychodynamic Psychiatry, 43(4), $523-$ 52. https://doi.org/10.1521/pdps.2015.43.4.523

Cutler, A. (2014). Leadership Psychology: How the Best Leaders Inspire Their People. Philadelphia, PA: Kogan Page.

Field Manual FM 6-22 Leader Development (2015). Amazon.de: US Army, U.S. Government: Fremdsprachige Bücher.

Haynes, A. (2017). Moving to the enlightened side: a sheep in wolf's clothing. BMJ Leader, 1, 46-47. http://dx.doi.org/10.1136/leader-2017-000045

Laurence, J. (2011). Military leadership and the complexity of combat and culture. Military Psychology, 23(5), 489-501. https://doi.org/10.1080/08995605.2011.600143

Sweeney, P. J. (2010). Do soldiers reevaluate trust in their leaders prior to combat operations? Military Psychology, 22, 70-88. https://doi.org/10.1080/08995601003644312

Taylor, R. L., Rosenbach, W. E. (2005). Military leadership: In pursuit of excellence. Cambridge, MA: Westview Press.

Vaughan, W. F. (1926). The psychology of compensation. Psychological Review, 33(6), 467479. https://doi.org/10.1037/h0070854

Wong, L., Bliese, P., McGurk, D. (2003). Military leadership: A context specific review. The Leadership Quarterly, 14(6), 657-692. https://doi.org/10.1016/j.leaqua.2003.08.001

\section{References (translated and transliterated)}

Bojko, O. (2019). Liderstvo yak dusha armiyi [Leadership as the Soul of the Army]. Retrieved from: https://petrimazepa.com/uk/liderstvo_yak_dusha_armii

Gladyshev, V. I. (2001). Kompensatornoe obshhenie: soczial no-filosofskij analiz [Compensatory Communication: A Socio-Philosophical Analysis]. Ph.D. dissertation. Ekaterinburg.

Zankovskiy, A.N. (2011). Psihologiya liderstva: ot povedencheskoj modeli k kulturno-cennostnoj paradigm [Psychology of Leadership: From Behavioral Model to Cultural and Value Paradigm]. Moscow: Institute of Psychology of the Russian Academy of Sciences. 
Petrenko, V.F. (2010). Mnogomernoe Soznanie: Psihosemanticheskaya Paradigma [Multidimensional Consciousness: A Psychosemantic Paradigm]. Moscow: Novy Khronograf.

Adams, D.L. (2009). Personality Type and Leadership Approach. Journal of Leadership Education, 8(2), 111-134. https://doi.org/10.12806/v8/i2/rf1

Adler, A. (2019). The Fundamental Views of Individual Psychology. The Journal of Individual Psychology, 75(3), 185-187. https://doi.org/10.1353/jip.2019.0023

Allen, N. (2006). Leader development in dynamic and hazardous environments: Company commander learning in combat. Doctoral dissertation, The George Washington University, Washington, DC.

Avolio, B.J. (2007). Promoting more integrative strategies for leadership theory-building. American Psychologist, 62(1), 25-33. https://doi.org/10.1037/0003-066X.62.1.25

Baran, B.E. \& Scott, C.W. (2010). Organizing Ambiguity: A Grounded Theory of Leadership and Sensemaking Within Dangerous Contexts. Military Psychology, 22, 42-69. https://doi.org/10.1080/08995601003644262

Bass, B., Bass, R. (2008). The Bass Handbook of Leadership: Theory, Research, and Managerial Applications. 4th Ed. New York: Free Press.

Bergman, D., Sendén, M.G., Berntson, E. (2019). Preparing to lead in combat: Development of leadership self-efficacy by static-line parachuting. Military Psychology, 31, 481-489. https://doi.org/10.1080/08995605.2019.1670583

Blanshard, C. (2019). Leadership in the spotlight. BMJ Leader, 3, 65-66. https://doi.org/10.1136/leader-2019-000155

Burgo, J. (2012). Why Do I Do That? Psychological Defense Mechanisms and the Hidden Ways They Shape Our Lives. Chapel Hill, NC: New Rise Press.

Cramer, P. (2015). Understanding defense mechanisms. Psychodynamic Psychiatry, 43(4), 523 552. https://doi.org/10.1521/pdps.2015.43.4.523

Cutler, A. (2014). Leadership Psychology: How the Best Leaders Inspire Their People. Philadelphia, PA: Kogan Page.

Field Manual FM 6-22 Leader Development (2015). Amazon.de: US Army, United States Government: Fremdsprachige Bücher.

Fomina, N. (2019). Otrazheniye v rechi individualno-tipologicheskikh osobennostei yazykovoi lichnosti [Reflection in speech of the individual-typological features of language personality]. Psycholinguistics, 26(1), 342-362. https://doi.org/10.31470/2309-1797-201926-1-342-362

Haynes, A. (2017). Moving to the enlightened side: a sheep in wolf's clothing. BMJ Leader, 1, 46-47. http://dx.doi.org/10.1136/leader-2017-000045

Laurence, J. (2011). Military leadership and the complexity of combat and culture. Military Psychology, 23(5), 489-501. https://doi.org/10.1080/08995605.2011.600143

Sweeney, P. J. (2010). Do soldiers reevaluate trust in their leaders prior to combat operations? Military Psychology, 22, 70-88. https://doi.org/10.1080/08995601003644312

Taylor, R. L., Rosenbach, W. E. (2005). Military Leadership: In Pursuit of Excellence. Cambridge, MA: Westview Press.

Vaughan, W. F. (1926). The psychology of compensation. Psychological Review, 33(6), 467479. https://doi.org/10.1037/h0070854

Wong, L., Bliese, P., McGurk, D. (2003). Military leadership: A context specific review. The Leadership Quarterly, 14(6), 657-692. https://doi.org/10.1016/j.leaqua.2003.08.001

\section{Source}

FB (Facebook). Retrieved from https://www.facebook.com/groups/655994877875713/ 